\title{
Spatial Epidemiology Occurrences of a Disease Pulmonary TB Smear (+) and Implementation Overview of Case Finding at Ciputat Health Center South Tangerang City, Banten Province in 2009-2013 \\ Wiwid Handayani, Minsarnawati Tahangnacca, and Riastuti Kusuma Wardhani
}

Faculty of Medicine and Health, State Islamic University Syarif Hidayatullah Jakarta, Jakarta, Indonesia

\section{Abstract}

Ciputat Health Center is a clinic in South Tangerang that has decreased detection rate of pulmonary TB smear $(+)$ by $30 \%$ in 2012-2013. Not yet implemented to case finding based spatial analysis made researcher wanted to know spatial epidemiology

Corresponding Author: Wiwid Handayani wiwid.handayani10@alumni uinjkt.ac.id

Received: 26 December 2018 Accepted: 23 February 2019 Published: 7 March 2019

Publishing services provided by Knowledge E

(c) Wiwid Handayani et al. This article is distributed under the terms of the Creative Commons Attribution License, which permits unrestricted use and redistribution provided that the original author and source are credited.

Selection and Peer-review under the responsibility of the $2 \mathrm{nd}$ International Meeting of Public Health 2016 Conference Committee. occurrences of a disease pulmonary TB smear $(+)$ and implementation overview of fact-finding at Ciputat Health Center, South Tangerang, Banten Province in 2009-2013. This research was epidemiology descriptive by design a case study supported by a qualitative approach - informants; holder of TB program, analyst laboratory, and nurse at Ciputat Health Center and vice supervisor of TB in Health Department South Tangerang. The object of research were 45 cases of pulmonary TB smear (+) that recorded in Ciputat Health Center years 2009 to 2013 and still had been living there until years 2014. The instrument of this research is the spatial data processing, meter, questionnaires, interview guides and a list of documents. The result was the distribution pattern of cases of pulmonary TB smear (+) in Ciputat Health Center was more clustered with the most disease occurrence in males, ages productive, low nutritional status, smoking behavior, little education and had a working condition. The overview of case finding activities by the implementation of netting suspected activities to have cluster pattern to the north, the village of Ciputat and inspection operation were not conducted on household contacts. Ciputat Health Center needed to do cloth suspected based on the design of the spread of cases and carried out household contacts.

Keywords: Spatial epidemiology; tuberculosis; case finding

\section{Introduction}

Tuberculosis (TB) is an infectious disease that still becomes a health problem in the community. It is a significant cause of disability and death in almost all countries around 
the world (Chin 2012). Globally, Indonesia ranked the fourth with the prevalence of cases TB in Indonesia in the years 2013 of 297 per 100.000 population (Kemenkes RI 2014).

TB case-finding is a first step that can significantly decrease the incidence of morbidity due to the amount of TB. This is due to the discovery of a case focusing on the DOTS strategy in the prevention of TB transmission so that it can cut the transmission and the prevalence of TB disease has decreased in society (Kemenkes RI 2011). Based on data from the Health Department of South Tangerang City (2014), it's found that there wasa decrease of case detection rate of pulmonary TB smear (+) (Case Notification Rate) at Ciputat Health Center, which was as much as 30 \% from the year 2012 until 2013.

According to Paul (2007), mapping of the region, especially mapping pattern disease pulmonary TB smear $(+)$ by using geographical information system (SIG), may help to build hypothesis of transmission pattern. Based on the introduction, it could be seen that Ciputat Health Center had not been carried out planning of case finding TB pulmonary smear $(+)$ by the spatial analysis approach to know occurrences of a disease pulmonary TB smear (+) especially pattern distribution in the region. In fact, according to research results Chrysantina (2004), the use of spatial analysis could provide information on the spread of TB cases in the area of Yogyakarta city.

\section{Methods}

This research was research epidemiology descriptive by design a case study and supported by a qualitative approach - the location of research was the Ciputat Health Center of South Tangerang which has two villages, namely Ciputat village and Cipayung village; conducted from May to July 2014. The population of research is the whole case of pulmonary TB smear (+) that still was alive and still lived in Ciputat Health Center in 2014 as many as 45 cases. The instruments of the data used in this research were the spatial data processing, meter, questionnaires, interview guides and a list of documents. Analysis of data used was occurrences analysis of a disease based on case characteristic, spatial analysis, and analysis with a qualitative approach.

\section{Results}

\subsection{Occurrences of a disease pulmonary TB smear (+)}

Occurrences of a disease pulmonary TB smear $(+)$ relate to the characteristics of a person. Based on research results, it could be seen that 45 of cases pulmonary TB smear 
(+) recorded in Ciputat Health Center 2009 - 2013. The characteristics of cases of pulmonary TB smear (+) greater found on that man as many as 28 cases (62\%) with the age of $15-50$ years, some 40 cases (89\%), having bony nutritional status as many as 36 cases (80\%), having smoking habit as many as 23 cases (51\%), 27 cases of low education (60\%), and work as many as 24 cases (53\%).

TABLE 1: Analysis Pattern the Spread of Cases Pulmonary TBSmear (+) at Ciputat Health Center in 2009-2013.

Parameters
The number of point cases
NNI
Pattern

\begin{tabular}{|c|c|c|c|}
\hline $\mathbf{2 0 1 0}$ & $\mathbf{2 0 1 1}$ & $\mathbf{2 0 1 2}$ & $\mathbf{2 0 1 3}$ \\
\hline 11 & 10 & 8 & 3 \\
\hline 0.71 & 0.85 & 0.93 & 1.52 \\
\hline Clustered & Clustered & Clustered & Random \\
\hline
\end{tabular}

\subsection{Case finding activity}

Here is an overview of suspicious netting activities and examination of household contacts at Ciputat Health Center in 2009-2013.

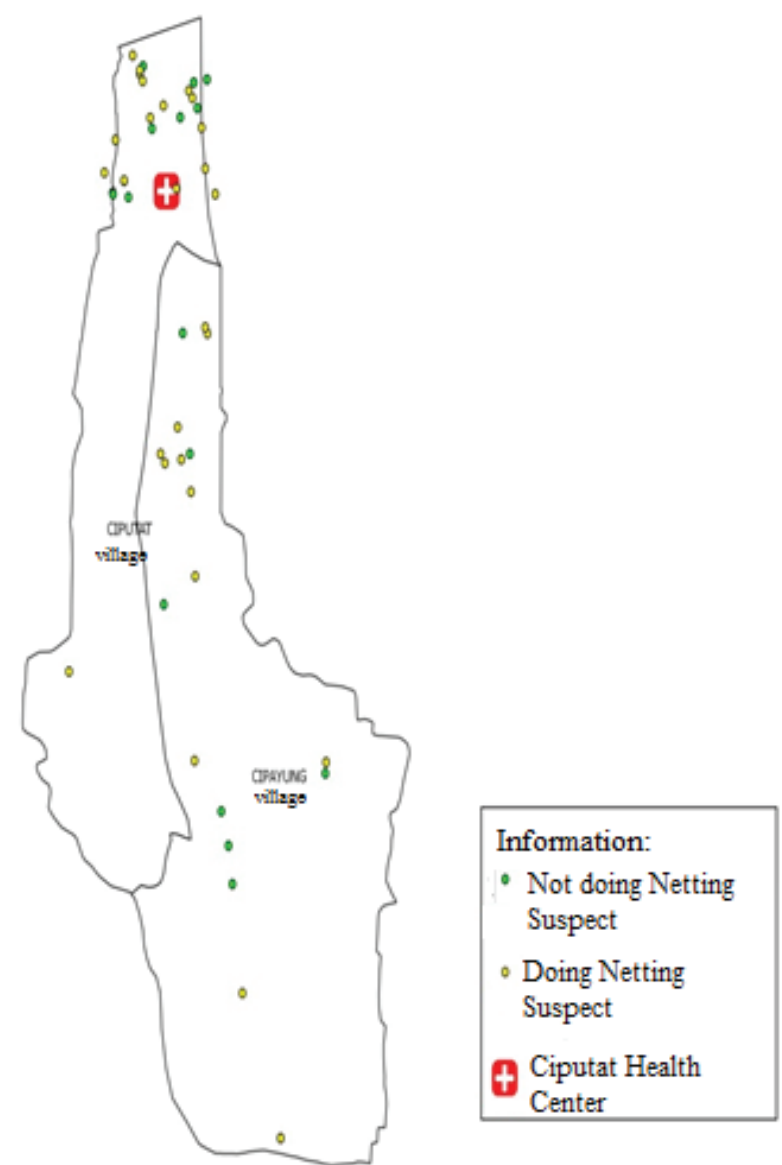

Figure 1: The Distribution of Netting Suspect Activities Based on Cases of TB Pulmonary Smear (+) at Ciputat Health Center in 2009-2013. 


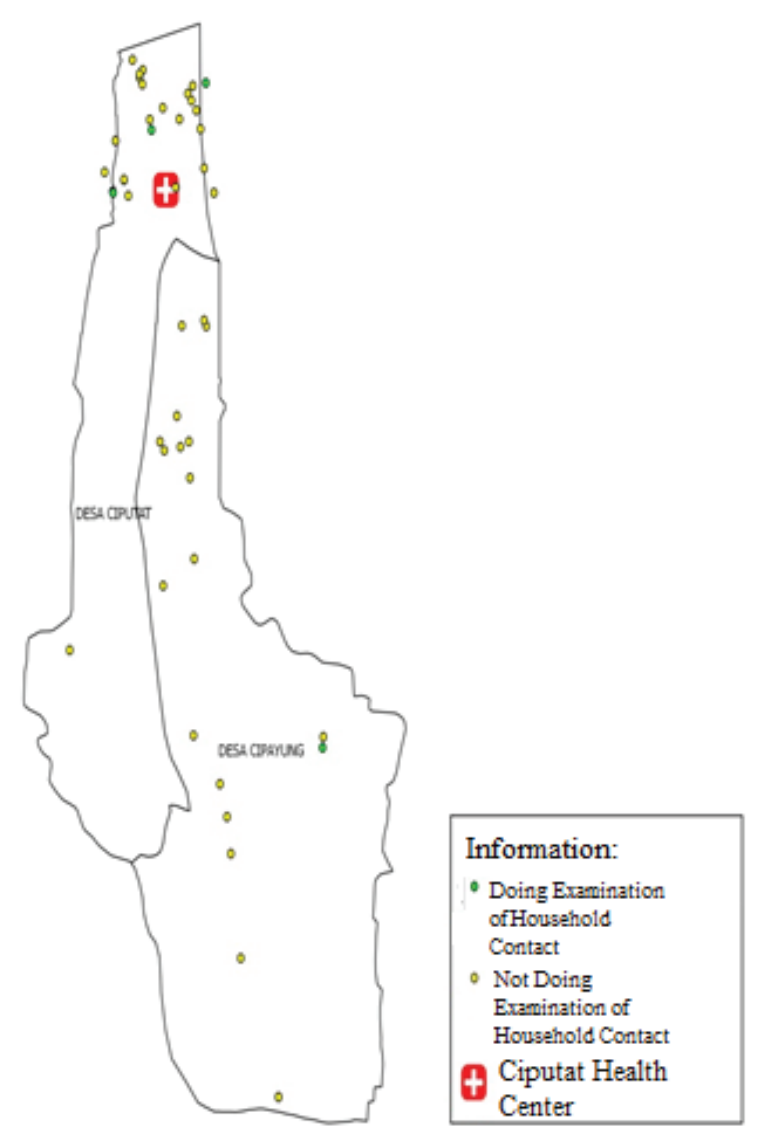

Figure 2: The Distribution of Examination of Household Contacts Based on cases of TB Pulmonary Smear $(+)$ at Ciputat Health Center in 2009-2013.

\section{Discussion}

From the results of research, the popular factors were the nutritional status and smoking. According to Notoatmodjo (2007), the lack of nutririon could cause a decrease of immunity/immune. Declining immune would cause a person susceptible to infectious diseases, such as TB. From the research of Wijaya (2012), it's known that cigarette smoke may lower respiratory tract defense so there would be moresusceptible to TB infection in smokers. The intervention related to the status of nutrition and smoking in society was needed.

On the spread of cases pulmonary TB smear (+), it's known that Ciputat Health Center had the cluster pattern. According to Timmreck (2005), when the disease in an area became a cluster pattern, this indicated to have a causation pattern. Therefore, further analysis related to the spread of disease pattern comparison between Ciputat Health Center and adjacent Health Center was needed. This was because Health Center was with Ciputat Health that could become the cause of a transmission source to occur the cases pulmonary TB smear (+) at Ciputat Health Center. 
In interviews with the holder of the TB program in Ciputat Health Center, its known that netting suspect activities of 2009-2013 done by examining someone suspected based on the symptoms arsing in such people. Netting suspect activities carried out by Ciputat Health Center were passive. Thiswas because there were no specific activities to net the case, no schedule, and not seen places as risk of the occurrence of pulmonary TB cases smear (+). linterviews by the holders of TB programs in Ciputat Health Center showed that household contacts of inspection activities were not done because some family members were reluctant to microscopic examination. Hence, there should be plans both regarding netting suspect and information related to the examination of household to people who had family members of TB patients.

\section{Conclusions}

Characteristic of cases pulmonary TB smear (+) in Ciputat Health Center within five years (2009-2013) were mostly shown by the lack of nutritional status and smoking habit, with a pattern of the spread of cluster. Ciputat Health Center needed to carry out case-finding based on the direction the design of dissemination of cases and interventions for the provision of information to the public related to TB disease.

\section{Acknowledgments}

We are very grateful to all those who have helped the research process, especially Ciputat Health Ciputat and Health Departement of South Tangerang City.

\section{References}

[1] Chin, James. 2012. Manual Pemberantasan Penyakit Menular. Edisi 17 Cetakan IV. Diterjemah oleh I Nyoman Kandun. Jakarta: Infomedika.

[2] Chrysantina. Kusnanto \& Fuad. 2004. Analisis Spasial dan Temporal Kasus Tuberkulosis di Kota Yogya. 2004. Yogjakarta: FKM FK UGM

[3] Kemenkes RI. 2011. Pedoman Nasional Pengendalian TB. Jakarta: Kemenkes RI Direktorat Pengendalian Penyakit dan Penyehatan Lingkungan.

[4] Kemenkes RI. 2014. Pedoman Nasional Pengendalian TB. Jakarta: Kemenkes RI Direktorat Pengendalian Penyakit dan Penyehatan Lingkungan.

[5] Notoatmodjo, S. 2007. Promosi Kesehatan dan Ilmu Perilaku. Jakarta: Rineka Cipta.

[6] Paul M, Kathleen K, Stephen M. 2007. Using health and demographic surveillance to understand the burden of disease in populations: The case of tuberculosis in rural 
South Africa.Scandinavian Journal of Public Health 35: 45-51.

[7] Timmreck, Thomas C. 2005. Epidemiologi Suatu Pengantar. Edisi 2. Jakarta: EGC.

[8] Wijaya, A.A. 2012. Merokok dan TB. Jurnal TB Indonesia, vol 8. Jakarta: PPTI. 